\title{
Graptolite Taxonomy and Classification
}

\author{
MU EN-ZHI
}

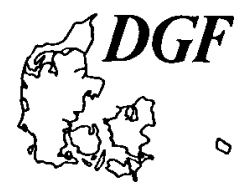

\begin{abstract}
Mu En-zhi: Graptolite Taxonomy and Classification. Bull. geol. Soc. Denmark, vol. 35, pp. 203-207, Copenhagen, July 1st, 1987. https://doi.org/10.37570/bgsd-1986-35-21

Graptolithina comprises chiefly six orders. Among them Graptoloidea anda part of Dendroidea known as Graptodendroids are planktonic in mode of life. Graptoloidea consists of threesubordersnamely Axonolipa, Axonocrypta and Axonophora. The families Dendrograptidae-Anisograptidae-Tetragraptidae and Didymograptidae-Isograptidae-Cardiograptidae-Diplograptidae-Monograptidae represent anagenetic grades. Some important evolutionary trends took place once again, representing cladogenetic divergences. All other families or subfamilies are offshoots of various grades. The suborder Axonocrypta is discussed in detail.
\end{abstract}

Mu En-zhi, Nanjing Institute of Geology and Palaeontology, Academia Sinica, Chimingssu, Nanjing, China, August 20th, 1986.

\section{General Consideration}

Graptolithina, a class of Hemichordata, comprises chiefly six orders known as Dendroidea, Graptoloidea, Tuboidea, Camaroidea, Stolonoidea and Crustoidea (Kozlowski, 1949, 1966; Bulman, 1970). The thecae in Dendroidea and Graptoloidea are regularly arranged in stipes, although Dendroidea has three kinds of thecae (autotheca, bitheca and stolotheca), while Graptoloidea has only one. In the graptoloid thecae, the proximal portion (protheca) and the distal portion (metatheca) are homologous with the stolotheca and autotheca respectively.

Among these orders, Dendroidea is the earliest in appearance (M. Cam.?, Late Cam.) and the latest in disappearance (Late Carb.); Graptoloidea ranged from Early Ordovician to Early Devonian; the other orders are rare in materials and known to occur from Ordovician to Silurian.

All the Tuboidea, Camaroidea, Stolonoidea, Crustoidea and most of Dendroidea are benthonic in the mode of life, whereas Graptoloidea and a part of Dendroidea are planktonic. The floating dendroids with free sicula appeared in the latest Cambrian (Fengshanian) and flourished in Early Xinchangian (Tremadocian), indicating a new stage in graptolite history. The graptodendroid family Anisograptidae comprising three subfamilies (quadriradiate Staurograp- tinae, tri-radiate Anisograptinae and biradiate Adelograptinae) is derived from the floating Dictyonema due to the loss of dissepiments $(\mathrm{Mu}$, 1974), while the reclined Psigraptidae Lin (1981) with isolated autothecae is an offshoot. Recently Zhao \& Zhang (1985) proposed a new family Muenzhigraptidae with biform autothecae representing the direct ancestor of Psigraptidae.

Graptoloidea first appeared in the late Xinchangian $\left(X_{3}\right)$ due to the loss of bithecae from Adelograptinae and flourished in early Ningkuoan $\left(\mathrm{N}_{1}\right)$, marking another new stage in graptolite history. Since then, Graptoloidea became the master of the quiet sea area in Ordovician and Silurian and even in Early Devonian.

\section{Subdivision of the Order Graptoloidea}

The subdivision of Graptoloidea has been treated by many graptolite workers. Two suborders, Axonolipa and Axonophora, proposed by Frech (1897) and emended by Ruedemann $(1904,1908)$ have been used for a long time $(\mathrm{Mu}, 1950$; Obut, 1957; Mu, 1974; Yu \& Fang, 1979). In fact, Axonolipa consists of Didymograpta and Dicellograpta of Lapworth (1880) and Axonophora consists of Diplograpta and Monograpta of Lapworth (1880). In the sixties, Jaanusson (1960) divided Graptoloidea into four suborders namely 
Didymograptina, Glossograptina, Diplograptina and Corynoidina. Bulmann (1963) grouped Corynoidina into the suborder Didymograptina and divided the Diplograptina into two suborders, Diplograptina and Monograptina. Mu \& Zhan (1966) established the suborder Axonocrypta in addition to Axonolipa and Axonophora based on the structure of the rhabdosome. Mu (1974) tentatively used Didymograpta and Dicellograpta as subdivisions of Axonolipa and Diplograpta and Monograpta as subdivisions of Axonophora respectively.

Axonolipa comprises the forms with nema free and the stipes pendent to reclined just like floating dendroids. Those in Didymograpta are developed in a primitive type. The initial bud originates from the porus on the ventral or dorsal side of the prosicula or the proximal part of metasicula. The proximal thecae grow downwards to nearly horizontally with one or two crossing canals, that is to say, the first or the second theca is dicalycal. The virgella is usually absent, or present in advanced forms, it begins at the proximal or middle part of the metasicula. The most primitive forms such as Didymograptus of Didymograptidae, Tetragraptus of Tetragraptidae and bitheca-lacking Clonograptus of Dichograptidae are the direct descendants of Adelograptinae of Anisograptidae. In Dicellograpta, the initial bud arises from the porus on the middle or distal part of metasicula. The proximal thecae grow horizontally to upwards with two or three crossing canals, that is to say, the second or third theca is dicalycal. The virgella is well developed, beginning usually at the proximal part of the metasicula. Dicellograptus of Dicranograptidae is the earliest derived from Didymograptidae.

In Axonocrypta the nema (virgula) is enclosed between the four to two scandent stipes. The sicula is relatively long. The initial bud originates from the porus on the prosicula or the proximal part of metasicula. It arises from the ventral, lateral or dorsal side of the sicula. The proximal thecae grow downwards or curved distally, with one or two crossing canals. The virgella is usually present in advanced form. Those with four or three stipes back to back (Phyllograptidae) are derived from Tetragraptidae, and those with two scandent stipes back to back (Cardiograptidae) or side to side (Glossograptidae) are derived from Isograptidae, a descendant of Didymograptidae (and Tetragraptidae?).

The suborder Axonophora comprises those with virgula embedded in the median septum in biserial form (Diplograpta) or in the dorsal wall of the periderm in uniserial form (Monograpta). In Diplograpta, the initial bud originates from the porus on the distal part of metasicula and even near the sicular aperture. The proximal thecae in early forms are curved upwards with three or more crossing canals; in some later ones, the crossing canals increase throughout the rhabdosome without dicalycal theca (aseptate). The virgella is well developed, beginning at the proximal part of the metasicula even near the prosicula. The most primitive genus Glyptograptus of Diplograptidae is most probably derived from Cardiograptidae of Axonocrypta due to the fusion of the dorsal walls of two stipes, forming a median septum. Exigraptus seems to be a transitional form between Cardiograptidae and Diplograptidae. In China, the earliest species of Glyptograptus, G. sinodentatus, direct ancestor of $G$. austrodentatus, is more closely related to Exigraptus (Mu et al., 1979; Chen, 1982). It is questionable that $G$. austrodentatus is derived from Maeandrograptus (Jenkins, 1980) and G. dentatus is related to Phyllograptus elongatus (Cooper \& Fortey, 1983).

In Monograpta the initial bud originates from the sinus on the distal part of the metasicula near the sicular aperture. The proximal thecae grow directly upwards without crossing canal, i.e., no dicalycal theca. The earliest representatives of Monograpta are Atavograptus (Rickards, 1974), Monoclimacis? (Bjerreskov, 1975) and Pristio. graptus ( $\mathrm{Li}$, in press) of Monograptidae, appearing abruptly in the beginning of Silurian (persculptus Zone) and representing another new stage of graptolite history. It is believed that Monograptidae is derived from Diplograptidae with discontinuity. Peiragraptidae and Dimorphograptidae are offshoots.

\section{On the Suborder Axonocrypta}

Axonocrypta linking with Axonolipa and Axonophora bears the fundamental characters between them in the structure of rhabdosome and 
in the mode of development. There are three families in Axonocrypta, known as Phyllograptidae, Cardiograptidae and Glossograptidae (= Cryptograptidae).

Phyllograptidae is directly derived from Tetragraptidae of Axonolipa with Tetragraptus phyllograptoides and Phyllograptus cor as the transitional forms (Cooper \& Fortey, 1982; Cooper \& Lindholm 1985). The Family Phyllograptidae was revised by Hsu (1934) and Mu \& Zhan (1966) to be composed of Phyllograptus and Trigonograptus (= Pseudotrigonograptus) based on the structure of the rhabdosome. Recently, Cooper \& Fortey (1982) revised this family to comprise Phyllograptus (s.s.) and a new genus Xiphograptus with two horizontal stipes, based on the origin of first theca from the dorsal side of the sicula and the presence of a virgella. In the writer's opinion, the orientation of the initial bud on the sicula is less taxonomic significance than the presence of virgella. Dorsal origin of initial bud on the sicula is also known in Didymograptus rozkowskae and Parazygograptus erraticus (Kozlowski, 1954), but with no virgella. Since the presence of virgella is an advanced feature, the virgella-bearing Phyllograptus (s.s.) is more advanced than Pseudophyllograptus without a virgella, and the virgella-bearing Xiphograptus is an advanced member in Didymograptidae. It is noteworthy that the virgella-bearing Pseudazygograptus incurvus (Ekström), the type species of Pseudazygograptus (Mu et al., 1960), with elaborated thecae is an advanced member in Azygograptidae (Finney, 1980, p. 1199, Textfigs. 9, 10). True Azygograptus with simple thecae and without virgella occurs in Arenigian of Europe and Ningkuoan $\left(\mathrm{N}_{4}\right)$ of the Yangtze Region and the Jiangnan subregion of the $\mathrm{S}$. China region in China, but is unknown in North America and Australasia.

In Phyllograptidae another advanced form is Pseudotrigonograptus uniformis $\mathrm{Mu}$ et Lee, the type of species of Pseudotrigonograptus (Mu and Lee, 1958, p. 417, PL. III, figs. 7-10). The detailed structure of the rhabdosome was described by Mu \& Lee (1958) and illustrated by Hsu \& Chen $(1964$, figs. 1, 4) based on the analysis of the pyritized thecae. The peculiar thecal characters and common canal and the parallel-sided rhabdosome in Pseudotrigonograptus uniformis are different from Pseudotrigonograptus ensiformis as described by Rickards (1973, p. 600, figs. 1-3). They are not conspecific. Cooper has rightly distinguished these two species based on the materials of New Zealand (Cooper, 1979, p. 91, figs. 83b-c).

The pore of the common canal in Pseudotrigonograptus uniformis corresponding to the "forenic foramina" in Phyllograptus typus illustrated by Cooper \& Fortey $(1982$, figs. $71 k, 74)$ is an advanced feature. The Spitzberg materials described by Fortey (1971) and Cooper \& Fortey (1982) as Pseudotrigonograptus ensiformis (4-stiped) and $P$. minor Mu et Lee (3-stiped) are possible new forms representing a genus intermediate between Pseudophyllograptus and Pseudotrinogograptus, because the stipes are not entirely overlapped laterally as in Pseudotrigonograptus and the serrated ventral margins of the stipes are clearly exposed. They are quite different from Pseudotrigonograptus ensiformis and $P$. minor $\mathrm{Mu}$ et Lee. This genus seems to be identical with Cooper's Gen. 1 from New Zealand (Cooper, 1979 , p. 93, figs. 84a-e). This genus is more primitive than Pseudotrigonograptus, it occurs in a lower horizon. The other two families of Axonocrypta, Cardiograptidae and Glossograptidae with two scandent stipes back to back and side to side respectively are derived from isograptidae. Cardiograptidae with two stipes back to back (dipleural) developed in platycalycal type and Glossograptidae with two stipes side to side (monopleural) developed in pericalycal type. Morphologically, Oncograptus is an intermediate form between Isograptus and Cardigraptus. Two distinct series in Oncograptus and Cardiograptus are recognized, namely, the upsilon-morsus series with wedge-shaped rhabdosome and the magnusamplus series with parallel-sided rhabdosome. The former occurs in North America, Australasia and the NW Region of China, whereas the latter is only known in the S. China Region. The relation between Oncograptus magnus and Cardiograptus amplus are possibly transitional, whereas the relation between Oncograptus upsilon and Cardiograptus morsus is uncertain, because an additional theca is present in Oncograptus upsilon (Bulman, 1936) and a distinct virgella is present in an allied species Oncograptus zhongguoensis Xu \& Huang (1979). Therefore, Onco- 
graptus is here placed in Isograptidae of Axonolipa. Skevington (1968) considered Oncograptus upsilon and Cardigraptus morsus to be conspecific derived from "Isograptus" manubriatus based on the so-called "curved" proximal thecae. Cooper (1979) demonstrated the proximal thecae in Oncograptus and Cardiograptus which grow downwards without curvature.

The characteristic feature of Glossograptidae is the overlapping of the two scandent stipes (monopleural). In Apiograptus Cooper \& McLaurin (1974) the two stipes begin to be overlapped laterally (Cooper, 1979). It was considered to be a primitive member of Glossograptidae (= Cryptograptidae) by $\mathrm{Mu}$ et al., 1979. In the advanced form, Cryptograptus tricornis, the two stipes are entirely overlapped. For the sake of clarity, the writer used formerly Hadding's Cryptograptidae instead of Lapworth's Glossograptidae, because Lapworth's Glossograptidae is fused with his Lasiograptidae. For the same reason, the writer proposed Hallograptidae instead of Lapworth's Lasiograptidae (Mu, 1950; Urbanek, 1959). It is unnecessary to divide the family Glossograptidae (= Cryptograptidae) into two families (Strachan, 1985).

\section{Anagenetic Grades and Cladogenetic Divergences}

As stated above, Axonocrypta links with Axonolipa and Axonophora. Dendrograptidae and Anisograptidae of Dendroidea, Tetragraptidae-Didymograptidae and Isograptidae of Axonolipa, Cardiograptidae of Axonocrypta and Diplograptidae and Monograptidae of Axonophora represent anagenetic grades. Some important evolutionary trends such as simplification and complication of rhabdosome, overlapping of stipes, elaboration of thecae and reduction of periderm, took place once again in the graptolite history representing cladogenetic divergences. The following taxa are all offshoots of various grades.

Simplification of rhabdosome: Azygograptidae and Corynoididae in Axonolipa, Peiragraptidae and Dimorphograptidae in Axonophora.

Complication of rhabdosome: Pterograptinae, Nemagraptinae (= Pleurograptinae) and Tangyangraptinae in Axonolipa, Diversograptinae,
Cyrtograptinae and Linograptinae in Axonophora.

Overlapping of stipes: Kalpinograptidae in Axonolipa, Glossograptidae (= Cryptograptidae) in Axonocrypta.

Elaboration of thecae: Muenzhingraptidae-Psigraptidae in Dendroidea, Sinograptidae, Kinnegraptidae, Atopograptidae and Dicranograptidae in Axonolipa, various lineages in diplogratids and monograptids in Axonophora.

Reduction of periderm: Abrograptidae in Axonolipa, Reteograptidae and Archiretiolitidae-Retiolitidae-Plectograptidae in Axonophora.

Studies on internal structure of graptolites afford important features of taxonomic significance:

1) The initial bud growing from the porus on the prosicula or on the proximal part of metasicula changes downwards to grow from the distal part of metasicula and the porus changes to a sinus.

2) The formation of a virgella beginning at the distal part of metasicula changes upwards to be at the proximal part of the metasicula.

3) The growth direction of the proximal thecae especially the first two pairs changes from downwards to upwards.

4) The formation of the median septum in scandent rhabdosome changes from a compound septum (median septa in Axonocrypta) to a simple septum (in Axonophora).

Ultrastructural studies of graptolites have provided some important information for graptolite taxonomy as reviewed by Rickards, Crowther \& Chapman (1982). Further studies on the microstructure and ultrastructure of the etched materials will settle well the problem of the graptolite taxonomy.

\section{Dansk sammendrag}

Graptolithina er sammensat af seks. ordener. Blandt dem er Graptoloidea og en del af Dendroidea kendt for deres planktoniske levevis. Graptoloidea er sammensat af tre underordener nemlig Axonolipa, Axonocrypta og Axonophora. Familierne Dendrograptidae-Anisograptidae-Tetragraptidae og Didymograptidae-Isograptidae-Cardiograptidae-Diplograptidae-Monograptidae representerer anagenetiske grader. Nogle vigtige evolutionære tendenser viste sig igen i form af cladogenetiske afspaltninger. Alle andre familier eller subfamilier er sideskud af forskellig grad. 
Underordenen Axonocrypta bliver diskuteret i nogen detalje i det nærværende arbejde.

\section{References}

Bjerreskov, M., 1975: Llandoverian and Wenlockian graptolites from Bornholm, Fossils \& Strata, 8., 94 pp.

Bulman, O. M. B., 1936: The structure of Oncograptus T. S. Hall, Geol. Mag., 73, 864, 271-278.

Bullman, O. M. B., 1963: The evolution and classification of the graptoloidea, Quart. Jl. geol. Soc. London, 119, 401418.

Bulman, O. M. B., 1970: Graptolithina with section on Enteropneusta and Pterobranchia, Treatise on Invertebrate Paleontology, part V, Geol. Soc. Amer. and Univ. Kansas, $163 \mathrm{pp}$.

Chen Xu, 1982, Early Ordovician Exigraptus and Glyptograptus from Xingan, N. Guangxi and the origin of Biseries Axonophorous graptoloids, Acta Pal. Sinica, 21, 5, 513-535.

Cooper, R. A., 1979: Ordovician geology and graptolite faunas of the Aorangi Mine area, Northwest Nelson, New Zealand, Pal. Bull., 47, New Zealand Geological Survey, 1127.

Cooper, R. A. \& Fortey,, R. A., 1982: The Ordovician Graptolites of Spitsbergen, Bull. Br. Mus. Nat. Hist. (Geol.) 36, 3, 157-302.

Cooper, R. A. \& Fortey, R. A., 1983: Development of the graptoloid rhabdosome, Alcheringa, 7, 201-221.

Cooper, R. A. and Lindholm, K., 1985: The phylogenetic relationships of the graptolites Tetragraptus phyllograptoides and Pseudophyllograptus cor. Geol. Foren. Stockholm Forh. 106, 3, 279-291.

Cooper, R. A. and McLaurin, A. N., 1974: Apiograptus gen. nov. and the origin of the biserial graptoloid rhabdosome, Special papers in Palaeontology, 13, 75-85.

Finney, S. C., 1978: The affinities of Isograptus, Glossograptus, Cryptograptus, Corynoides, and allied graptolites. Acta Palaeontologica Polonica, 23, 4, 481-495.

Finney, S. C. 1980: Thamnograptid, Dichograptid and Abrograptid graptolites from the Middle Ordovician Athens Shale of Alabama, Jour. Palaeont., 54, 6, 1184-1209.

Fortey, R. A., 1971: Tristichograptus, A Triserial Graptolite from the Lower Ordovician of Spitsbergen, Palaeontology, $14,1,188-199$.

Frech, F., 1897: Lethaea geognostica I, Lethaea palaeozoica, 1, Leipzig, $690 \mathrm{pp}$.

Hsu, S. C., 1934: Graptolites of the Lower Yangtze Valley, Monograph Nat. Res. Inst. Geol., A 4, 106 pp.

Hsu, S. C. \& Chen, P. L., 1964: On the genus Trigonograptus, Scientia Sinica, 13, 4, 639-653.

Jaanusson, V., 1960: Graptoloids from the Ontikan and Viruan (Ordov.) Limestones of Estonia and Sweden, Bull. geol. Inst. Univ. Uppsala, 38, 289-366.

Jenkins, C., 1980: Maeandrograptus schmalenseei and its bearing on the origin of the diplograptids. Lethaia, 13, 289302.

Kozlowski, R., 1949: Les Graptolithes et Quelques Nouveaux Groupes d'Animaux du Tremadoc de la Pologne. Paleontologia Polonica, iii, 1948, 235 pp.
Kozlowski, R., 1954: Sur la structure de certains Dichograptids. Acta Geol. Polonica, 4, 423-444.

Kozlowski, R., 1966: On the structure and relationships of graptolites, Jour. Palaeont. 40, 3, 489-501.

Lapworth, C., 1980: On the geological distribution of the Rhabdophora. Ann. Mag. Nat. Hist. V, 5, 45-62, 273-285, 359-369; vol. 6, pp. 16-29, 185-207.

Lin Yao-kun, 1981: New Materials of Graptodendroids with special reference to the Graptodendroidea. Bull. Nanjing Inst. Geol. Paleont. Acad. Sinica, 3, 241-262.

$\mathrm{Mu}, \mathrm{A}$. T., 1950: On the evolution and classification of Graptoloids. Ti-chih-lun-ping, 15, 4-6, 171-183. (in Chinese).

Mu, A. T., 1974: Evolution, Classification and Distribution of Graptoloidea and Graptodendroids, Scientia Sinica, 17, 2, 227-238.

Mu, A. T. \& Lee, C. K., 1958: Scandent graptolites from the Nangkuo Shale of Kiangshan-Changshan area, western Chekiang, Acta Palaeont. Sin., 6, 4, 391-428.

Mu, A. T., Lee, C. K. \& Geh, M. Y., 1960: Orodvician graptolites from Xinjiang, Acta Palaeont. Sinica, 8, 1, 27-39.

Mu, A. T. \& Zhan, S. G., 1966: On the probable development and systematic position of Glossograptus. Scientia Sinica, $15,92-98$.

Mu En-zhi, Ge Mei-yu, Chen Xu, Ni Yu-nan \& Lin Yao-kun, 1979, Lower Ordovician graptolites of wouthwest China. Palaeont. Sinica, 156B (13), 1-1921.

Obut, A. M., 1957: Classification and ordering of the genera of graptolites. Vsesoyuz. Paleont. Obshch. Ezhegodnik 16, 11-47. (in Russian).

Rickards, R. B., 1973: The Arenig graptolite genus Pseudotrigonograptus Mu et Lee, 1958, Acta geol. Polonica, 23, 4, 597-604.

Rickards, R. B., 1974: A new monograptid genus and the origins of the main monograptid genera. Special Paper in Palaeontology 13, 141-147.

Rickards, R. B., Crowther, P. R. and Chapman, A. J., 1982, Ultrastructural studies of graptolites - a review, Geol. Mag., 119, 4, 355-370.

Ruedemann, R., 1904: Graptolites of New York, Part I: Graptolites of the lower beds. N. Y. State Mus., Mem., 7, 457803.

Ruedemann, R., 1908: Graptolites of New York, part II: Graptolites of higher beds. N. Y. State Mus., Mem. 11, 1-583.

Skevington, D., 1968: The affinities of Oncograptus, Cardiograptus and allied graptolites from the Lower Ordovician; Lethaia, 1, 4, 311-324.

Strachan, 1., 1985: The significance of the proximal end of Cryptograptus tricornis (Carruthers) (Graptolithina), Geol. Mag. 122, 2, 151-155.

Urbanek, A., 1959: Studies on graptolites II, on the development and structure of graptolite genus Gymnograptus Bulman, Acta Palaeont. Polonica, IV, 3, 279-338.

$\mathrm{Xu}$ Jie \& Huang Zhi-gao, 1979: Lower Ordovician graptolite faunas of Guozigou Area, Hocheng, Xinjiang. Acta geol. Sinica, 1979, 1, 1-19.

Yu Jian-hua \& Fang Yi-ting, 1979: On the classification of graptoloids. Acta Palaeont. Sinica. 18, 5, 435-443.

Zhao Xiang-lin \& Shang Zhun-xin, 1985: Reclined graptolites of the Xinchangian. Journal of Changchun College of Geology, 1985 (2), 13-26. 